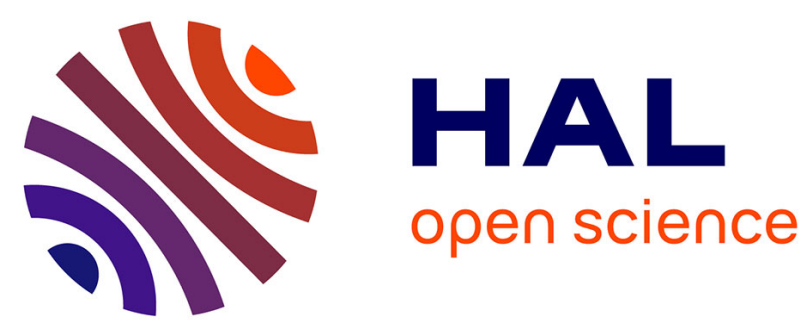

\title{
Energy consumption in service industries: Challenging the myth of non-materiality
}

\author{
Charlotte Fourcroy, Faïz Gallouj, Fabrice Decellas
}

\section{To cite this version:}

Charlotte Fourcroy, Faïz Gallouj, Fabrice Decellas. Energy consumption in service industries: Challenging the myth of non-materiality. 9th International Conference of the European Society for Ecological Economics. Advancing Ecological Economics, European Society for Ecological Economics, Jun 2011, Istanbul, Turkey. 10.1016/j.ecolecon.2012.07.003 . hal-01111724

\author{
HAL Id: hal-01111724 \\ https://hal.science/hal-01111724
}

Submitted on 30 Jan 2015

HAL is a multi-disciplinary open access archive for the deposit and dissemination of scientific research documents, whether they are published or not. The documents may come from teaching and research institutions in France or abroad, or from public or private research centers.
L'archive ouverte pluridisciplinaire HAL, est destinée au dépôt et à la diffusion de documents scientifiques de niveau recherche, publiés ou non, émanant des établissements d'enseignement et de recherche français ou étrangers, des laboratoires publics ou privés. 
9th International Conference of the European Society for Ecological Economics, Challenging the myth of non-materiality: energy consumption in service industries, Bogazici University, Istanbul, Turkey, June 14-17 2011.

Challenging the myth of non-materiality. Energy consumption in service industries.

Charlotte Fourcroy, Faïz Gallouj,

Clersé, Université Lille 1

Fabrice Decellas

EDF-R\&D

\begin{abstract}
This paper addresses the issue of energy consumption in service industries. Official energy statistics show that the amount of energy consumed in service industries is quite small, and this is explained in the theoretical literature by the presumed intangibility of these services. Our hypothesis, however, is that the energy consumed by services has been underestimated. After identifying and analyzing the full range of sources of energy consumption in service industries, we show that official energy statistics account for only a part of this consumption. Our work is based on a thorough rereading of the economics literature on services (especially concerning the definition of services and the specifics of the service provision process), done in light of our knowledge about energy consumption.
\end{abstract}

Key words : Service industries, Energy consumption, Materiality

\title{
Introduction
}

In economic theory, services are often described as "non-material", "immaterial" or "intangible" (Smith, 1776; Say, 1803; Sismondi, 1819). This non-materiality would explain their having smaller negative impact on the environment and lower energy consumption than does industry. Inasmuch as growth in recent decades has been largely driven by the development of services, a number of studies, particularly in the early 1990s, have argued that we are trending towards an ever more non-material society creating less environmental wear (Ettighoffer, 1992; Romm et al., 1999). Against such conclusions, however, we would note that the most service-intensive countries are as a whole greater consumers of energy, with a larger ecological footprint, than countries whose tertiary sector is less developed (Gadrey, 2010). Given the vital stakes involved in bringing energy demand under control, 
primarily due to the threats of diminished fossil resources and climate change, it is important to come down on one side or the other of these opposing arguments and identify the conditions that might foster sustainability in the service economies.

In this study we consider the question of the non-materiality of services from the viewpoint of their energy consumption. The following are our hypotheses: (1) service businesses are not as non-material as has been imagined, and (2) they consume non-trivial amounts of energy, which are underestimated in the official statistics. To consider this question it is necessary to understand the forms which energy demand takes in the service sector. There are rather few theoretical studies concerned with energy consumption in the services sector. Our analyses are based on a review, guided by the question of energy consumption, of the theoretical literature on services which is concerned with their definition and an analytical breakdown of how they are provided.

The first part of the paper is devoted to a discussion of what might be called the myth of the non-materiality of services. In the second part we attempt, on the basis of a theoretical breakdown of the provision of services, to identify all the sources of direct energy consumption by services. We show that the official energy statistics account for only a part of energy consumption. By taking a life-cycle perspective on services, we have broadened our view so as to identify energy consumption indirectly related to the provision of services. The third and final part of the paper is devoted to an attempt to estimate the magnitude of neglected energy consumption, or at least, within the limited scope of this paper, some of it.

\section{The myth of the non-materiality of services}

One can trace the origin of the term non-materiality (or intangibility) of services to Adam Smith and his analysis of the accumulation of capital. In his work The Wealth of Nations (1776), Smith distinguishes two types of economic activity: productive work, like that of the worker who adds value to the materials he handles and transforms, and unproductive work which adds no value. Among the unproductive activities Smith identifies the activities we today term services. ${ }^{1}$ Although the adjective "non-material" is never directly used, the idea of non-materiality is implicit, as the following examples illustrate: "the [unproductive] labour does not fix or realize itself in any permanent subject, or vendible commodity, which endures after that labour is past, or for which an equal quantity of labour could afterwards be procured" (ibid., p. 430), "the work of all [the services] perishes in the very instant of its production" (ibid., p. 431).

\footnotetext{
${ }^{1}$ He specifically mentions the services of the State, artists, etc.
} 
In a discussion of the accumulation of capital, Jean-Baptiste Say (1803) questions the term unproductive. Indeed, although they produce no value, the services are to Say useful and sources of visible outcomes (e.g. the cure produced by a physician). He therefore introduces the term immaterial. Most of his contemporaries used some version of this term, which was to become the leading feature used in describing service businesses. To 19th century economists the non-materiality of a service meant that the service is consumed and produced simultaneously (Say, 1803), that its outcome does not take a material form, that it cannot be accumulated (Sismondi, 1819) and that it does not produce an exchangeable value (H. Storch $)^{2}$ ).

In the 20th century, when the notion of a services sector first appeared, the adjective non-material was settled on it as well. The idea of non-materiality of services was then fleshed out by an assumed lesser usage of plant and equipment (i.e. less capital intensity). Thus Colin Clark observed that most service businesses require far less in the way of capital goods than industry or agriculture (Clark, 1940, p. 207)

A number of contemporary studies, however, question the notion that non-materiality fairly characterizes services (Fuchs, 1968; Delaunay, Gadrey, 1987; Illeris, 1989; Gadrey, 1992). Transportation and communications services are among the most capital intensive. They require the use of a great deal of equipment. Furthermore, certain services are performed upon media which are tangible goods (book and newspaper publishing, sculpture, painting, ${ }^{3}$ etc.), while other services repair, maintain or transform tangible goods (repair and maintenance services, not to mention restaurants and food services), or move them about (transportation, wholesale and retail trade, etc.) or make them available to users (rental services). In contemporary economies, the invasiveness of information and communications technologies also casts doubt on this notion of non-materiality. All service businesses today make use of information and communications technologies (ICTs), which in some cases give a physical form to the service (a recording of a course, for example).

Be that as it may, the notion of the non-materiality of services remains a chief feature by which service operations can be distinguished from other economic activities. In their attempts to propose a positive definition of services ${ }^{4}$, Peter Hill and Jean Gadrey preserve non-materiality as an essential characteristic of services. Thus Peter Hill (1977) defines services as a change in the condition of a

\footnotetext{
${ }^{2}$ Heinrich Storch, 1823. The Course of Political Economy, or an Exposition of the Principles which Determine the Prosperity of Nations. Cited in Delaunay and Gadrey, 1987.

${ }^{3}$ These activities are classified as services since it is generally acknowledged that their informational content exceeds their physical content (Illiens, 1989). According to INSEE, printing and the mass production of recordings belong in the industrial sector.

${ }^{4}$ The positive definition is distinct from a residual definition, as rounding out all the other economic activities.
} 
person or a good ${ }^{5}$, and Jean Gadrey stresses that a service business does not result "in the production of a good that can circulate economically apart from its medium" (Gadrey, 1992, p. 19). Other arguments can be brought in to support the continued notion of non-materiality as a relevant analytic category to describe services. Such is the case, for instance, with the analysis of the post-industrial society dominated by service businesses and founded on knowledge and information (Bell, 1973; Stehr, 2007; Aoyama et Castells, 2002; Foray, 2000).

Against the current background of diminishing natural resources and environmental deterioration, the notion of non-materiality of services has often been taken to mean that services have a low impact on the environment and in particular that they consume less energy (Illeris, 2007; Rifkin, 2000; OCDE, 2000). This idea is corroborated by a number of empirical observations. In France's energy accounting, services in 2006 represented only $14 \%$ of total consumption (Mairet, 2009) whereas in the same year they represented $75.1 \%$ of value added and $74.7 \%$ of total domestic employment (INSEE national accounts). Thus the energy intensity of the value added by service businesses is on average much lower than by other sectors. Likewise, in France's $\mathrm{CO} 2$ emissions accounting (data from CITEPA $^{6}$ ), the services sector represented only $7 \%$ of emissions in 2008.

Figure 1. Energy intensity of value added, by sector (Mtoe/BEUR 2000$)$ in 2006

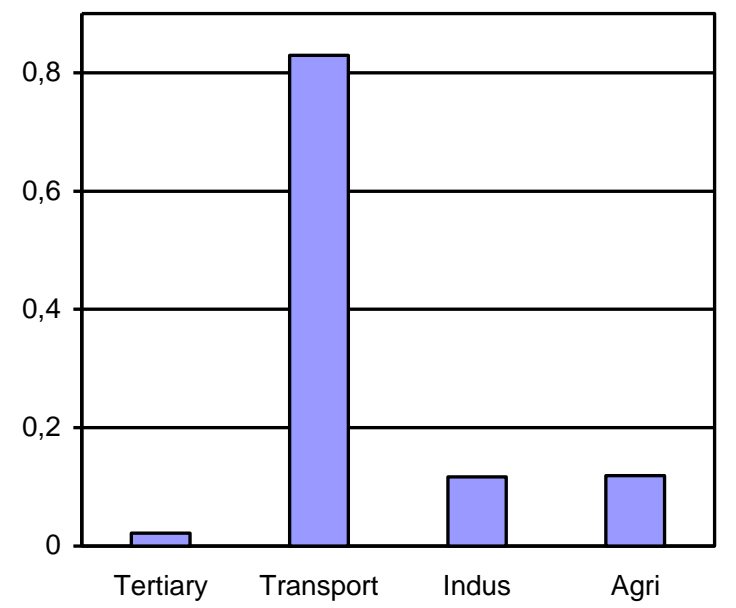

Source: Author's calculations using data from CEREN and INSEE

The idea that services, being non-material, consume less energy and exert less pressure on the environment is a highly attractive one, as it means that the increasing service orientation of an economy, which is the unstinting trend in every developed country, will automatically foster

\footnotetext{
5 "A service may be defined as a change in the condition of a person, or a good belonging to some economic unit, which is brought about as the result of the activity of some other economic unit, with the prior agreement of the former person or economic unit" (Hill, 1977, p. 318). In another article (Hill, 1999), however, Hill states that non-materiality is not an exclusive feature of services and that there is also such a thing as a non-material good.

${ }^{6}$ Data from CITEPA for 2008 relating to CO2 emissions, excluding LULUCF (Land Use, Land-Use Change and Forestry).
} 
sustainability. This idea has taken hold with governments and is defended by the OECD (OECD, 2000) and the European Union in its Lisbon Strategy.

We will devote the sections that follow to demonstrating that the non-materiality of services - the presumed basis of their low environmental impact - is a myth and to examining the consequences of that in terms of energy consumption.

\section{Finding overlooked sources of energy consumption}

The task before us at this point is to propose a theoretical breakdown of service provision, which reveals the main dimensions of its materiality and therefore its main sources of energy consumption. We distinguish between direct energy consumption, which is that required for and during the provision of services, and indirect energy consumption, which is brought about in the rest of the economy by service businesses.

\subsection{Breakdown of service provision and direct energy consumption}

Our theoretical breakdown of service provision is based on a rereading, from an energy viewpoint, of works that focus on the definition of services. The earliest works dealt largely with the distinction between goods and services and with the shared characteristics apparent among all services (Smith, 1776; Say, 1803; Sismondi, 1819; Marx, 1971; Fisher, 1939; Clark, 1940; Fourastié, 1949). Although a number of contemporary authors have attempted to work out a truly positive definition of services (Hill, 1977 and 1999; Gadrey, 1992) ${ }^{7}$ none of their definitions is entirely satisfactory, and the boundaries of the services sector remain fuzzy and dependent on the conventions chosen (Illeris, 1989). Still other studies have concentrated on describing service businesses within themselves (Gadrey, 1991; Gallouj, 1999; Eiglier, Langeard, 1987). And this is the perspective we take as well.

A service rendered by a provider for one or more customers (consumer or user, payer or beneficiary) will be a combination of various operations (Gadrey, 1991; Gallouj, 1999):

- logistics and material transformation (M), which consist of transforming, moving or maintaining tangible objects;

- logistics and information processing (I), which consist of producing, entering, circulating, archiving and processing coded information;

- the mental processing of knowledge $(\mathrm{K})$;

\footnotetext{
${ }^{7}$ The definitions of services formulated by these two authors are mentioned in part in the preceding section.
} 
- relational services $(\mathrm{R})$, which are direct services performed on the customer himself.

Performing these operations results in an outcome that can be described in terms of the final features of the service (Gallouj, Weinstein, 1997; Gallouj, 2002). In the case of lodging services, for example, the service features are primarily rest, comfort, cleanliness, access to recreation, or information, etc. ${ }^{8}$ Producing the service features by carrying out the various operations means putting to work the qualifications and techniques of the service provider-and of the customer. As embodied in an individual or a group of individuals, these competencies are the product of people's training, experience, interactions, etc. They may be of a scientific, technical, operational, interpersonal or other nature. They are sometimes codified but most often tacit. The technologies, on the other hand, are always codified; they exist apart from the individual and can be transmitted among individuals. They may or may not take tangible form. Thus M-type operations make use of material processing technologies such as mechanical technologies; I-type operations use information processing technologies (ICTs); K-type operations use non-material technologies, and codified procedures such as methodologies and protocols, while R-type operations may use this entire set of technologies (Gallouj, Weinstein, 1997 ; Gallouj, 1999 ; Gallouj, 2002).

The values prized by providers and their customers will also play a part in the provision of services. Values and competencies, when aligned with motivation, determine the behaviour of individuals (McClelland, 1985). The customer is at the centre of the provision of services. ${ }^{9}$ His or her part in the production of a service can take different forms-from self-service when using an automated cash dispenser to collaboration with the provider in the case of advisory services. This participation can even be solicited in advance of the production of service; the customer must at times travel to where the service is performed. The customer's level of involvement will vary. For certain services (a plane trip, for instance) only the customer's presence is necessary; for others (such as a training program) his attention is required (Eiglier, Langeard, 1987; Lovelock et al., 2004). One portion of the service often takes place in direct contact with the customer ${ }^{10}$; another portion is invisible to him, this being the internal organization of the service company (also called the back-office), consisting, for example, of the marketing, finance, human resources or logistics departments (Eiglier, Langeard, 1987).

\footnotetext{
${ }^{8}$ These features are not always easy to identify, especially in the case of non-standardized services requiring a high level of qualification, such as intellectual and professional services (Gallouj, 2002; Gallouj, Weinstein, 1997).

${ }^{9}$ It is even the view of Eiglier and Langeard (1987) that without the customer there is only a "potential" for service. Thus, for example, if a hotel room is not occupied for one night, there are no services. One may object, however, that it all depends on the definition of services that is used, since a part of the production of the service has taken place - the preparation of the hotel room. We shall return to this point when considering a broader definition of services. Furthermore, the participation of the customer is not necessary with respect to prevention services (defense, police, security patrols, etc.)

${ }^{10}$ However, ICTs include the remote delivery of services.
} 
Most of the above-mentioned technologies consume energy in order to function. These energyconsuming technologies are a major part of the information and communications technologies used in information processing operations. They include office machinery (computers, fax, telephones, photocopiers, etc.) and network and telecommunications infrastructure (servers, hubs, data centres, telephone exchanges, etc.). Today in France, almost all service businesses are equipped with computers and connected to the Internet (SESSI, 2008); and 20\% of the energy consumption in the services sector is directly attributable to the use of ICTs $^{11}$ (Mairet, 2009). In the area of materials processing operations, moreover, certain service activities require the use of other specialized equipment. Here we are talking about such things as equipment for material handling, cooling systems, cooking (restaurants), sanitary hot water $^{12}$ (swimming pools) or other particular production processes (such as laundries or bakeries).

Services, however, are not limited to the M, I, K and R operations we have just mentioned and that we propose designating "service delivery". Other activities related to the provision of services must be brought into any discussion of energy consumption.

Indeed, service deliveries necessitate interactions between provider and customer, and thus usually travel by one to the other, before the delivery. Students and teachers travel to their campus, patients to their doctor, etc. ${ }^{13}$ This travel is a source of pollution (Gadrey, 2010; Desmarchelier and Gallouj, 2010) and energy consumption.

Service delivery also requires various preparatory activities, such as preparing the place where the service is to occur (improvements, cleaning, heating, etc.), as well as the preparation of the provider (training, lodging, etc.). This preparation does occur only in advance of the delivery; it can be extended during the delivery (heating or illuminating the space, for example). For this reason, rather than the term "preparation" we prefer to use "conditioning" to denote this type of activity. A portion of this conditioning requires energy consumption, primarily for heating, sanitary hot water, lighting and air-conditioning the premises where the service occurs. This energy consumption is not specific to services, in that it also affects industry. What is specific is the weight it has in a company's total energy balance. Heating represents half the energy consumed in the services sector. One explanation for this trait is that, as opposed to industrial operations, service operations generally use less heavy equipment needing high energy inputs. Another explanation is the importance of personal meeting and meeting places in the provision of services. A service is produced jointly; customers and providers usually interact in a common space, which has to be conditioned for the services to be provided.

\footnotetext{
${ }^{11}$ That is, about $4 \%$ of final energy consumption in the tertiary sector.

${ }^{12}$ This is hot water for sanitary uses: rest rooms, food preparation, etc. It is often shortened to SHW.

${ }^{13}$ The different choices as to how service is delivered and therefore of travel, as well as the thinking behind them, are discussed in Section 3.
} 
In sum, service provision is a combination of the following three elements: delivery, conditioning and travel — each of which represents a separate, direct consumption of energy. Depending on the type of service business considered, there will be some variance in the activity level, operating cycle, need for delivered services, conditioning or travel involved. Performing these various services prompts a need for "energy services", which is to say, for example, a task, a change of place or an increase in temperature. This need for "energy services" varies as a function of a number of exogenous factors, including the outdoor climate and sources of indoor or cost-fee heat ${ }^{14}$. The actual energy consumption necessary to meet this need for "energy services" is, for its part, a function of the tangible property used and its technical characteristics - such as energy-using machinery and the building in which it is located-as well as how this property is used-i.e., individual behaviour. ${ }^{15}$ The general process by which energy demand is formed is illustrated in Erreur ! Pas de séquence spécifié.

Figure 2. General Process of the Formation of Energy Demand

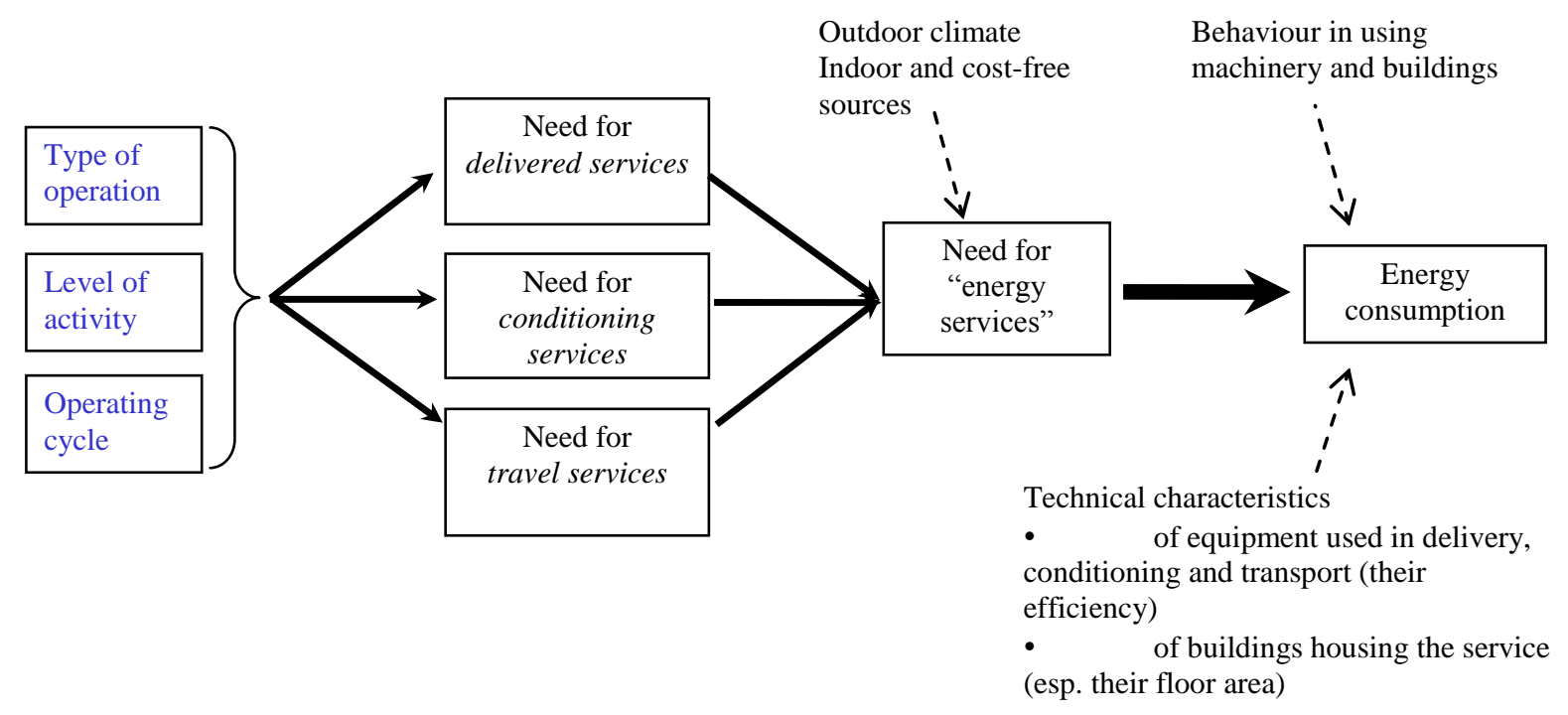

Not all the sources of energy consumption and related consumption that we have just identified in this analysis are accounted for in the official statistics (Erreur ! Référence non valide pour un signet.). In the CEREN statistics ${ }^{16}$, the energy consumption of the services sector is limited to those associated with the buildings used by the sector, that is, to the energy consumption of the equipment used on the premises ${ }^{17}$ of service companies (CEREN scope ${ }^{18}$ ). Thus, no accounting is given of energy consumed

\footnotetext{
${ }^{14}$ Indoor or cost-free heat largely derives, respectively, from other occupants or machinery in the building and sunshine.

${ }^{15}$ This approach to energy consumption is inspired by that proposed by Château and Lapillonne, cited by Nicolas Mairet (2009).

${ }^{16}$ CEREN: Centre d'Etude et de Recherches Economiques sur l'Energie [Centre for study and research into energy economics]. This is the major organization in France supplying energy statistics on the tertiary sector.

${ }^{17}$ By service business premises we mean the entire floor area of service companies, including any parking lots or other outside areas. The premises may be owned or leased.
} 
in the course of providing the services from the operation of off-site equipment or means of transportation (for travel services, but at times for delivered services). Yet it is true that services, especially as they are produced jointly, require considerable travel and sometimes occur completely or in part outside of the service company.

Figure 3. The Scope of Energy Consumption in the tertiary sector as assumed in CEREN statistics

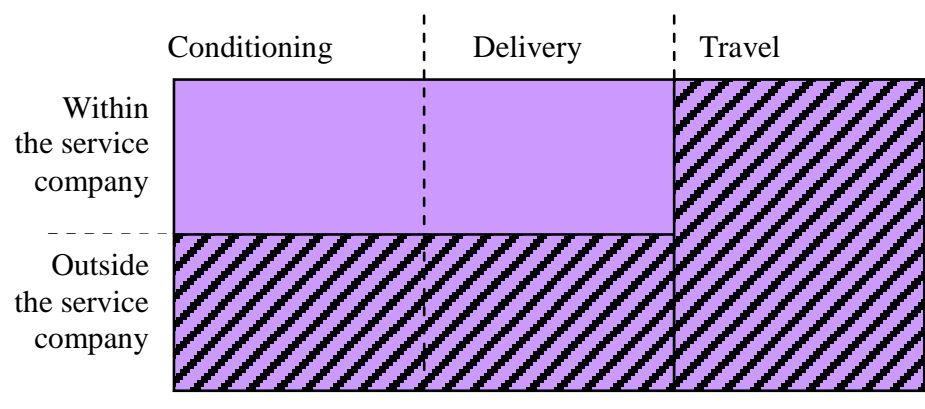

Operation of energy-consuming equipment

Key:

Consumption excluded in the CEREN energy statistics

We have identified three sources of materiality in services that constitute as many sources of direct energy consumption: service delivery, travel and conditioning. Yet still other energy consumption is necessary for services, even if the energy in question is not directly consumed during the provision of the service. That is the topic of the following section.

\subsection{Energy consumption indirectly related to the provision of services}

As we have just emphasized, the operation of equipment enlisted for delivery, conditioning and travel makes up a sizable source of energy consumption. We must not forget, however, that this equipment had to be made and that its manufacture is also a source of energy consumption-energy for the design of the project, the extraction and transportation of the necessary raw materials, the processing of raw materials and fabrication of the product. Marketing this equipment, maintaining and recycling it also give rise to energy expenditures. All of this energy consumption, although indirectly related to the provision of services, cannot be excluded from a discussion of energy consumption in the tertiary sector. By including this indirect energy consumption into our analysis we are adopting a product life-cycle approach. The value of such an approach is that it gives a truer picture of the energy impact

\footnotetext{
${ }^{18}$ CEREN defines the boundaries of the services sector in terms rather similar to those proposed by INSEE.
} 
(and more broadly, the environmental impact) of service operations. But to do so means defining the boundaries of the system we are studying.

Accordingly, in the indirect energy consumption of a given service, which we shall call "the final service", one must include the grey energy ${ }^{19}$ of equipment used in delivery, conditioning and travel. Producing the final service also requires other types of goods, such as buildings, furnishings, infrastructure (transportation and telecommunication) and other intermediary consumption of goods (food products, for example, in a food service business). The grey energy of these goods is tied to the production of the final service, and we choose to include it in our approach.

Apart from equipment and tangible goods, producing a final service also at times requires the intermediary consumption of other services. The marginal increase in activity of these intermediary services and the associated marginal energy consumption are tied to the production of the final service. The energy consumption of these intermediary services is itself defined as the sum of energy consumption in the operation of their energy-using equipment and the grey energy of their equipment, furnishings, buildings, infrastructure, etc.

Figure 4. The total direct and indirect sources of energy consumption in a final service represents the system as seen at the scale of the final service. This energy consumption indirectly related to service operations is plainly not included in the official statistics on the tertiary sector.

\footnotetext{
${ }^{19}$ The expression grey energy or embodied energy of a good means the total energy consumption necessary for the production, manufacture and recycling of a good, i.e. the phases that precede and follow the use of a good.
} 
Figure 4. The total direct and indirect sources of energy consumption in a final service

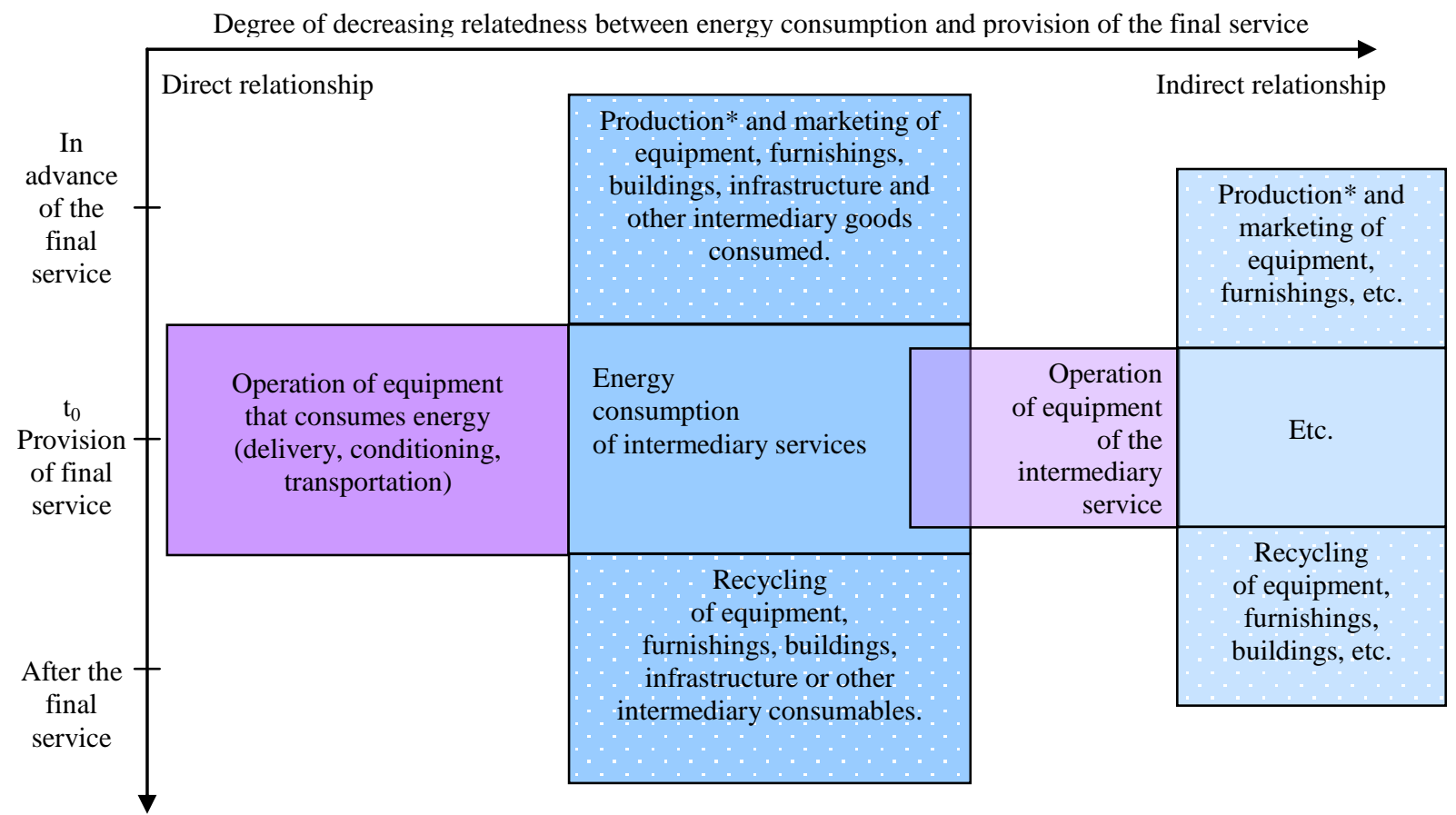

Grey energy of equipment, furniture \& furnishings, buildings, infrastructure, etc.

*Production in the broad sense. This includes: the design of the project, the extraction and transportation of the necessary raw materials, the processing of raw materials and fabrication of the product.

\section{Towards a new methodology for energy consumption accounting in the tertiary sector}

Lastly, we are proposing an alternative methodology to account for energy consumption, one that derives from our theoretical construction of the sources of energy consumption in the tertiary sector. Our hope is to contribute a more realistic assessment — which is to say, a reassessment —of the amount of energy necessary to provide a service. It is not our claim, however, that we are proposing a re-allocation of energy consumption among the various economic sectors. It might become necessary to consider that some portion of services is directed towards industrial production.

Within the scope of the French tertiary sector, the energy consumption overlooked by the official statistics is as follows:

- One part of energy consumption that goes for operating service equipment:

(1) Energy consumption for the operation of means of transportation (in service travel and delivery);

(2) Energy consumption for the operation of off-site equipment used for service delivery and conditioning. 
- Energy consumption indirectly related to the provision of services:

(3) The grey energy of equipment, furnishings, buildings, infrastructure and all intermediary consumables;

(4) The energy it took to produce imported intermediary services ${ }^{20}$.

The total of this energy consumption is not available in the form of invoices or shipping statements. This consumption is classified with other energy consumption not related to services - in the energy consumption of other institutional sectors. The total therefore has to be estimated. Such work generally requires using surveys of a representative sample of the population. To the traditional biases that characterize surveys $^{21}$, one might have to add occasional lack of information or ignorance on the part of the respondents ${ }^{22}$. On account of such difficulties and given the available data, we restrict ourselves in this paper to estimating energy consumption for the operation of means of transportation, i.e., type 1 consumption. By demonstrating that type 1 energy consumption is not trivial compared to the official tertiary sector energy consumption figures and that it represents a significant portion of energy consumption in the transportation sector, we are confirming empirically what we had previously conceived theoretically: that the tertiary sector consumes more energy than the official energy statistics would lead one to believe.

Nor is the total amount of type 1 energy consumption available on invoices or shipping statements. To estimate its size we have made use of the findings of the 1993-1994 French national transportation and travel survey (French acronym ENTD) ${ }^{23}$. Although this survey is nearly 20 years old, it does allow us, by comparing the findings made about energy consumption in the tertiary sector in 1993, to estimate the approximate extent of the consumption for travel overlooked by the official statistics. A representative sample of the French population was questioned as to the trips they had made. For a few representative days (one weekday and one weekend), the respondents furnished the reasons for, the distances involved in and the means of conveyance of all of trips they made. The respondents also supplied information about themselves, including their socio-professional status. Making a few assumptions, which we lay out in Section 4.1, we have estimated the travelling done by consumers and providers of services (section 4.2).

\footnotetext{
${ }^{20}$ Within the French tertiary sector and to avoid double counting services, intermediary services are limited to imported intermediary services.

${ }^{21}$ Especially the bias that misunderstanding or social acceptability can throw into responses.

${ }^{22}$ This is particularly the case with households who do not know their energy consumption by type of use.

${ }^{23}$ The transportation survey was repeated in 2007 , but the data to which we have access are incomplete and do not permit us to estimate type 1 consumption.
} 


\subsection{Assumptions}

In order to estimate from the INSEE transportation survey the energy consumption created by all the travel originating in the consumption or production of services, we formulated several assumptions relative to the reasons for trips made, the business sectors involved, the combination of means used and the energy efficiency of those means.

a) Reasons for travel

For every trip made, the survey results show the reason for it, taken from a predefined list. We have organized this list by distinguishing those reasons we deemed to be directly related to the consumption of a service and those we deemed to be job-related (including commuting from home to work).

Table 1. Reason for travel and consumption of services

\begin{tabular}{|c|c|}
\hline $\begin{array}{l}\text { Reason for travel related to the consumption of } \\
\text { services }\end{array}$ & Work-related reasons for travel \\
\hline Place of study (school, high school, university) & Going to a fixed, customary workplace \\
\hline Day care, nursery school & \multirow{2}{*}{$\begin{array}{l}\text { Going to an unfixed workplace (construction site, } \\
\text { business meeting, business trip, etc.) }\end{array}$} \\
\hline Shopping mall or downtown stores & \\
\hline Neighbourhood store and other shopping & \multirow[t]{2}{*}{ Coming home from workplace } \\
\hline $\begin{array}{l}\text { Medical treatment or personal care (doctor, hairdresser, } \\
\text { etc.) }\end{array}$ & \\
\hline Government-related errands & \multirow[t]{3}{*}{ Other work-related reasons } \\
\hline $\begin{array}{l}\text { Accompanying or picking up someone at a train station, } \\
\text { airport, subway stop, etc. }\end{array}$ & \\
\hline $\begin{array}{l}\text { Cultural and athletic events or meetings (cinema, theatre, } \\
\text { concert, sports match, etc.) }\end{array}$ & \\
\hline Visiting monuments and historical places & Other reasons for travel \\
\hline Playing sports (gymnastics, soccer, etc.) & Going home \\
\hline Recreational locations (parks, fairs, bowling, etc.) & Visiting family \\
\hline Going on vacation & Visiting friends \\
\hline Cafés, restaurants, bars & Going to a second home or occasional dwelling \\
\hline Going to a training program, lecture, conference, etc. & \multirow[t]{3}{*}{ Other personal reasons } \\
\hline $\begin{array}{l}\text { Accompanying or picking up someone at one of the } \\
\text { aforementioned places }\end{array}$ & \\
\hline Returning home from one of the aforementioned places & \\
\hline
\end{tabular}

b) Business sectors

With regard to work-related travel, our estimate must only include that done by individuals who work in service firms or organizations. The survey provides no information on the business sector of the individuals surveyed. We therefore relied on their socio-professional status (SPS), which was part of the questionnaire, and we posited that within a single socio-professional status the distances travelled are spread evenly among those working in the different sectors-i.e., that the share of distance 
travelled by service providers is proportional to the share of workers in the tertiary sector. INSEE gives the data for the intersection of socio-professional status and business sector. The data are not available for the 1993-1994 year of the survey. The closest date for which they are available is $1999 .^{24}$ The data are presented in Erreur ! Référence non valide pour un signet.

Table 2. Intersection of socio-professional category and business sector

\begin{tabular}{|c|c|c|c|}
\hline SPS & Tertiary sector & SPS & Tertiary sector \\
\hline 10 Farmers & $0.0 \%$ & 47 Technicians & $52.6 \%$ \\
\hline 21 Craftsmen & $38.4 \%$ & 48 Foremen & $39.4 \%$ \\
\hline 22 Wholesalers, Retailers & $97.9 \%$ & 52 Government employees & $99.3 \%$ \\
\hline 23 Business owners & $60.9 \%$ & 53 Police and military & $96.9 \%$ \\
\hline 31 Members of the professions & $98.7 \%$ & 54 Business employees & $81.1 \%$ \\
\hline 33 Government white-collar & $98.3 \%$ & 55 Wholesale/retail employees & $90.2 \%$ \\
\hline $\begin{array}{l}\text { Teachers, secondary \& } \\
\text { higher }\end{array}$ & $98.9 \%$ & 56 Personal services & $98.7 \%$ \\
\hline $35 \mathrm{IT}$, arts professionals & $83.6 \%$ & 62 Skilled industrial workers & $16.5 \%$ \\
\hline 37 Business executives & $82.9 \%$ & 63 Skilled craftspersons & $51.9 \%$ \\
\hline 38 Engineers & $52.3 \%$ & 64 Drivers & $85.6 \%$ \\
\hline 42 School teachers & $99.0 \%$ & $65 \begin{array}{l}\text { Skilled maintenance, } \\
\text { warehousing workers }\end{array}$ & $68.5 \%$ \\
\hline $43 \begin{array}{l}\text { Healthcare intermediary } \\
\text { professions }\end{array}$ & $97.2 \%$ & 67 Unskilled industrial workers & $36.0 \%$ \\
\hline 44 Clergy, religious vocations & $98.1 \%$ & 68 Unskilled craftsmen & $66.4 \%$ \\
\hline $\begin{array}{l}45 \text { Government intermediary } \\
\text { workers }\end{array}$ & $99.0 \%$ & 69 Farm workers & $14.1 \%$ \\
\hline $\begin{array}{l}\text { Business intermediary } \\
\text { professions }\end{array}$ & $77.9 \%$ & & \\
\hline
\end{tabular}

Source: INSEE, 1999 census of the population

c) Multiple means of transportation

To estimate the energy consumption from distances travelled, it is necessary to know the means of transportation used and its average consumption rate. It is not unusual for a person to use more than one means of transportation for a single trip. For each trip reported in the ENTD survey, information is given on the total distance travelled and the different conveyances used, but distance is not broken down by conveyance. We have therefore made estimates. We made the assumption that for each trip the first two means of travel mentioned are the chief, if not the only, means used. We then formulated a number of assumptions as to the breakdown of distance travelled between these two means

\footnotetext{
${ }^{24}$ Despite the gap in time, we believe that these data are useful, inasmuch as we are trying to estimate the approximate amount of energy consumption.
} 
(Table 3), based on a study conducted as part of the ETHEL project. ${ }^{25}$ The results of this study show, for example, that on average an individual who makes a trip by car and by train covers $15 \%$ of the distance by car and $85 \%$ of the distance by train.

${ }^{25}$ ETHEL: Energie, Transport, Habitat, Environnement, Localisations [= Energy, Transportation, Habitat, Environment, Locations]. A project conducted in 2003 whose findings are available at http://ethel.ishlyon.cnrs.fr/index.htm. The assumptions about multiple means of transportation are based on analyses of surveys. 
Table 3. Assumptions about multiple means of transportation

Means of transportation

On foot, by bicycle and all other means of transportation

Airplane and all other means

Train and car

Train and coach

Train and other means

Coach and car

Coach and bus

Coach and other means

Car and bus

Car and two-wheeled vehicles

Car and other means

Bus and other means

\section{Breakdown of distances travelled}

$100 \%$ of the distance attributed to the other means

$100 \%$ of the distance attributed to the airplane

$15 \%$ of the distance attributed to the car

$85 \%$ of the distance attributed to the train

$100 \%$ of the distance attributed to the train

$30 \%$ of the distance attributed to the car

$50 \%$ of the distance attributed to each means

$100 \%$ of the distance attributed to the coach

$35 \%$ of the distance attributed to the car

$100 \%$ of the distance attributed to the car

$35 \%$ of the distance attributed to the car

$50 \%$ of the distance attributed to each means

Source: Data from the ETHEL project, arranged to match our means of transportation

d) The energy efficiency of means of transportation

Lastly, we made assumptions as to the per unit consumption of each means of transportation. For mass transit, we made assumptions about the energy consumption per kilometre travelled and per traveller. With regard to two-wheeled vehicles and cars, insofar as in both cases the number of people in or on the vehicle is indicated in the ENTD survey ${ }^{26}$, we preferred to consider the energy consumption by kilometre travelled and then divide it by the number of people in or on the vehicle. For truck transport, we assumed that the driver is alone in the vehicle.

We ignored energy consumption related to travel by foot, bicycle, boat and conveyances not in the survey. (This approximation seems reasonable in that according to the findings of the ENTD 1993 survey, these last two means of transportation represent less than $6 \%$ of the kilometres travelled by the French public.)

The ENTD survey provides useful data for estimating the energy consumption of automobiles. It provides various data about vehicles owned, in particular their average consumption, in and out of the city, by type of energy consumed (diesel or petrol). We make the assumption that the weighted average of these consumption numbers (weighted by the proportion of households in the French population) is representative of the average consumption per kilometre of all cars and taxis. The results obtained are presented in Erreur ! Référence non valide pour un signet.

\footnotetext{
${ }^{26}$ With respect to the few trips for which the number of people is not indicated (less than $1 \%$ of trips by motorbike and by car), we made the assumption that the person was alone on/in the vehicle. Since the number of trips without data is very low, this assumption will have very slight effect on the final result.
} 
Table 4. Average energy consumption per vehicle per $100 \mathrm{~km}$

\begin{tabular}{c|cc} 
& City driving & Outside the city \\
\hline Petrol & $7.6 \mathrm{~L}$ & $8.5 \mathrm{~L}$ \\
Diesel & $6.8 \mathrm{~L}$ & $7.4 \mathrm{~L}$
\end{tabular}

Source: Author's calculations based on the ENTD survey results

A litre of petrol equals about $9.85 \mathrm{kWh}$ and a litre of diesel, $10.58 \mathrm{kWh}$. According to the ENTD 1993 survey, $72.3 \%$ of cars on the road in France run on petrol.

The breakdown of trips between city and non-city driving can also be estimated from some of the survey data. The survey results cover total trips, as well as, at times, the number of kilometres travelled in the city, on the highway and on other roads. We made the following assumption: trips made on highways and other roads equal the non-city trips. Trips for which the kilometres travelled on each type of road are reported in the ENTD survey allow us to calculate a pattern of trips among the different geographic areas. We made the assumption that this pattern applies to the breakdown of all trips. We found that $20 \%$ of the kilometres are travelled in the city and the rest outside the city. Finally, according to our calculations, cars and taxis in 1993 consumed on average $0.81 \mathrm{kWh} / \mathrm{vehicle-}$ kilometre.

To estimate the consumption of the other means of transportation, we relied on a study conducted by the Deloitte firm for ADEME (ADEME/Deloitte 2008). This study is recent, whereas the ENTD survey dates from 1993. We therefore made assumptions regarding the improvements in energy efficiency of transportation between these two years. Between 1990 and 2009, the total energy efficiency of transportation appears to have improved by about $12 \% .^{27}$ We therefore made the assumption that for each means of transportation the per unit consumption when in use decreased by $12 \%$ between the time of the ENTD survey and the ADEME/Deloitte study. In addition, our transportation categories are not completely identical to those in the study. We made assumptions to establish some correspondence between them. The per unit consumption of school and company buses (codes 41 and 42) are thought to be similar to coaches; that of trolleys and other unlisted roadway mass transit (codes 55 and 59), similar to buses; that of trains would be the average of high-speed trains, regional express trains and Paris commuter trains. ${ }^{28}$ The per unit consumption supplied by the ADEME/Deloitte study is expressed in grams of petroleum equivalent per passenger-kilometre and we have converted that to kilowatt-hours per passenger-kilometre. Using the international energy conversion tables, 1,000 GPE equals about $11.63 \mathrm{kWh}$. For mass transit, per unit consumption is

\footnotetext{
${ }^{27}$ http://www.odyssee-indicators.org/publications/country_profiles_PDF/fra_nl.pdf

${ }^{28}$ These assumptions could be improved upon, especially by studying the breakdown of trips among high-speed rail, regional express lines and Parisian commuter rail. But we believe that these assumptions are satisfactory for our current purpose, which is to estimate approximate amounts of energy consumption.
} 
presented in The breakdown of trips between city and non-city driving can also be estimated from some of the survey data. The survey results cover total trips, as well as, at times, the number of kilometres travelled in the city, on the highway and on other roads. We made the following assumption: trips made on highways and other roads equal the non-city trips. Trips for which the kilometres travelled on each type of road are reported in the ENTD survey allow us to calculate a pattern of trips among the different geographic areas. We made the assumption that this pattern applies to the breakdown of all trips. We found that $20 \%$ of the kilometres are travelled in the city and the rest outside the city. Finally, according to our calculations, cars and taxis in 1993 consumed on average $0.81 \mathrm{kWh} /$ vehicle-kilometre.

Table 5. Energy consumption of various means of transportation

\begin{tabular}{cc} 
Means of transportation & $\begin{array}{c}\text { Energy consumption per passenger per kilometre } \\
(\mathrm{kWh} / \text { passenger-km) }\end{array}$ \\
\hline High-speed rail & 0.09 \\
Trains & 0.15 \\
Parisian rapid transit rail system & 0.09 \\
Coach & 0.13 \\
Bus & 0.46 \\
Tram & 0.08 \\
Subway & 0.09 \\
Airplane & 0.53 \\
Truck & 4.10 \\
\hline
\end{tabular}

Source: Author's calculations based on data from the ADEME/Deloitte study (2008)

Lastly, in the ADEME/Deloitte study, the per unit consumption of two-wheeled vehicles is defined for different geographic areas (urban, peri-urban, regional and interregional). As for car travel, the ENTD survey provides us with total trips on two-wheeled vehicles, as well as, at times, the kilometres travelled on two wheels in the city, on the highway and on other roads. We make the following assumptions: travel in the city corresponds to urban travel; travel on highways, to interregional travel; travel on other roads, half to peri-urban travel and half to regional travel. Trips for which the kilometres travelled on each type of road are reported in the ENTD survey allow us to calculate a pattern of trips among the different geographic areas. We made the assumption that this pattern applies to the breakdown of all trips (Erreur ! Référence non valide pour un signet.). Finally, according to our calculations, two-wheeled vehicles in 1993 consumed on average $0.41 \mathrm{kWh} /$ vehicle-kilometre.

Table 6. Breakdown of two-wheeled vehicle travel by geographic area Urban Peri-urban Regional Interregional 


\begin{tabular}{c|cccc}
\hline Travel by two-wheeled vehicle & $37 \%$ & $25 \%$ & $25 \%$ & $13 \%$ \\
\hline \multicolumn{4}{c}{ Source: Author's calculations based on the ENTD } & 1993 survey results
\end{tabular}

\subsection{Results of our estimates}

From the assumptions made, we estimated the energy consumption for all trips related to the consumption and production of services. The energy consumption is estimated using the following formulas:

- Energy consumption due to travel by service consumers:

$$
\sum_{t}\left(52 \times \sum_{s}\left(\sum_{i}\left(\sum_{j} d_{s i j} \times p_{i} \times p_{j}\right)\right)\right) \times C_{t}
$$

- Energy consumption due to travel by service providers, for commuting and work-related trips:

$$
\sum_{t}\left(52 \times \sum_{p}\left(\sum_{i^{\prime}}\left(\sum_{j} d_{p i^{\prime} j} \times p_{i^{\prime}} \times p_{j}\right)\right)\right) \times C_{t}
$$

where: $\mathrm{t}=$ means of transportation;

$\mathrm{s}=$ trips occasioned by the consumption of services;

$\mathrm{p}=$ work-related trips (including commuting);

$\mathrm{i}=$ individuals surveyed;

i' = individuals surveyed who work in the tertiary sector;

$\mathrm{j}=$ day of the week;

$\mathrm{C}_{\mathrm{t}}$ : estimate of the average consumption of the means of transportation, per $\mathrm{km}$ and per passenger;

$d_{\text {sij }}$ and $d_{p^{\prime} j}$ : distance travelled per trip, per individual and per day;

${ }_{\mathrm{p}} \mathrm{i}$ and $\mathrm{p}_{\mathrm{i}}$ : occurrence of such an individual in the French population (how representative he or she is);

$\mathrm{p}_{\mathrm{j}}$ : weight given to the day the questionnaire was administered so that the results can be representative of one week;

The results obtained are presented in Erreur ! Référence non valide pour un signet.. 
Table 7. Estimate of energy consumption for travel related to service operations

\begin{tabular}{|c|c|c|c|}
\hline & $\begin{array}{l}\text { Trips occasioned by the } \\
\text { consumption of services } \\
\text { (in km) }\end{array}$ & $\begin{array}{l}\text { Work-related trips of service } \\
\text { providers } \\
\text { (in } \mathrm{km})\end{array}$ & $\begin{array}{l}\text { Corresponding energy } \\
\text { consumption (TWh) }\end{array}$ \\
\hline $\begin{array}{l}\text { On foot and } \\
\text { by bicycle }\end{array}$ & $5,893,092,030$ & $958,519,983$ & 0.0 \\
\hline $\begin{array}{l}\text { Two-wheeled } \\
\text { vehicles }\end{array}$ & $1,476,415,676$ & $973,440,727$ & 0.9 \\
\hline Car and taxi ${ }^{2 y}$ & $117,731,351,689$ & $79,858,954,616$ & 107.9 \\
\hline Truck & $3,371,509$ & $353,113,534$ & 1.5 \\
\hline Coach & $13,295,234,475$ & $1,418,965,640$ & 1.8 \\
\hline Bus & $5,181,805,725$ & $1,592,388,322$ & 3.1 \\
\hline Subway & $1,816,700,221$ & $1,942,969,762$ & 0.3 \\
\hline $\begin{array}{l}\text { Parisian rapid } \\
\text { transit rail system }\end{array}$ & $889,974,273$ & $1,301,089,674$ & 0.2 \\
\hline Tram & $204,965,724$ & $114,212,944$ & 0.0 \\
\hline High-speed rail & $2,525,628,236$ & $740,213,412$ & 0.3 \\
\hline Other trains & $4,380,144,378$ & $5,464,916,676$ & 1.5 \\
\hline Airplane & $12,349,394,854$ & $2,752,202,840$ & 8.0 \\
\hline Other & $1,485,687,260$ & $246,192,283$ & 0.0 \\
\hline Total & $167,233,766,049$ & $97,717,180,413$ & 125.7 \\
\hline
\end{tabular}

In 1993, about 126 TWh of final energy appear to have been consumed for travel associated with service operations. This amount represents about $25 \%$ of the consumption in the transportation sector for that year and $70 \%$ of the consumption in the tertiary sector. If one reassigns the type 1 energy consumption, the weight of the tertiary sector in the total energy balance increases from about $10.5 \%$ to over $18 \%$.

If one places these results into the current situation, in which the consumption in the transportation sector amounts to $584 \mathrm{TWh}$ and that of the tertiary sector to $225 \mathrm{TWh}^{30}$, one comes up with $145 \mathrm{TWh}$ and 158 TWh respectively. Furthermore, INSEE supplies an estimate of the change in travel distances between 1993 and 2007 for a few travel purposes (Erreur ! Référence non valide pour un signet.).

\footnotetext{
${ }^{29}$ Distances travelled by car, taxi and two-wheeled vehicles appearing in the table equal the total distances travelled by all French people. To estimate the corresponding energy consumption, we first divided these distances by the number of passengers travelling by that means.

${ }^{30}$ These data are from 2008 and are provided by SOeS and CEREN, respectively.
} 
By further updating the results of the 1993 survey based on these data ${ }^{31}$, we obtain an estimate of the energy consumption for travel related to service businesses on the order of $140 \mathrm{TWh}$.

Table 8. Change in distance travelled, by purpose $(\%)$

\begin{tabular}{l|cccccc} 
& Work & Study & Shopping & $\begin{array}{c}\text { Home to other } \\
\text { activities }\end{array}$ & $\begin{array}{c}\text { Other } \\
\text { trips }\end{array}$ & Total \\
\hline Rural and thinly settled areas & 26 & 22 & 29 & 2 & 0 & 12 \\
Densely populated areas & 10 & Not sig. & Not sig. & -10 & -1 & -1 \\
\hline
\end{tabular}

Source: Insee/SOeS/Inrets, ENTD 1993, transportation and travel survey 2007-2008

It thus seems a reasonable inference that the energy consumption required today for travel to consume services and to provide services is on the order of 140 to $160 \mathrm{TWh}$. If one reassigns this energy consumption to the tertiary sector, the latter's weight in the total energy balance would then almost reach $20 \%$.

\section{Conclusion}

In economic theory, the supposed non-materiality of services has suggested that a highly service-oriented society would consume less energy. But the non-materiality of services is a myth. The very interactivity that is understood to be one of the essential characteristics of a service shows itself as the major source of their materiality, since it relies upon physical communications and transportation systems. In this paper we have identified various sources of materiality in the service sector, and they are all sources of energy consumption. We have also shown that services consume energy through the different stages of their provision, whether by travel and the conditioning of service premises or by the actual delivery of services. We have also shown that their production requires numerous goods (equipment, buildings, infrastructure, etc.) whose grey energy needs to be taken into account when considering the energy impact of the service sector. In the energy statistics of the tertiary sector, only a portion of the energy consumption truly required by the provision of services is recognized.

Within the limited scope of this paper, we have only estimated one of the sources of energy consumption that have been overlooked in the official statistics: that pertaining to mobility. (That is, we estimated travel by service consumers to consume the service, and the commuting travel and work-related travel by service providers). Travel is important for two reasons: first, because it captures

\footnotetext{
${ }^{31}$ Also in need of updating are the per unit consumption of the means of transportation and the intersection between SPS and business sector. Here we have relied on the results of the ADEME/Deloitte study and the results of the INSEE 2007 census, respectively.
} 
the interactivity of services, which is one of their major characteristics, and secondly, because it is a major source of their materiality. We estimate that the reassignment of this energy consumption has the effect of multiplying the tertiary sector's consumption by a factor of about 1.7. Efforts need to be undertaken to make estimates of the other sources of energy consumption, for the energy required by the entire tertiary sector is far greater than what we have estimated here.

We have confirmed all of our assumptions theoretically and some of them empirically, as follows: the tertiary sector is in reality far from non-material, and the provision of services calls for significant amounts of energy consumption that the official statistics underestimate due to their accounting methodology. The increasing service orientation of an economy therefore does not constitute a solution to its energy, or more broadly, environmental issues.

This conclusion raises the question of the reciprocal relationship between service sector innovation and tighter energy constraints. 


\section{BIBLIOGRAPHY}

ADEME/Deloitte, 2008. Efficacité énergétique, emissions de CO2 et autres émissions gazeuses spécifiques des modes de transport, Rapport final.

BAUMOL William, 1967. "Macroeconomics of unbalanced growth: the anatomy of urban crisis", American Economic Review, Vol. LVII, n³, June, pp. 415-426.

BELL Daniel, 1973. The coming of post-industrial society, a venture in social forecasting, Basic Books, New-York ; trad. fr. 1976. Vers la société post-industrielle, Laffont, Paris, 446p.

BOURG Dominique, BUCLET Nicolas, 2005. "L'économie de la fonctionnalité. Changer la consommation dans le sens du développement durable", Futuribles, n³13, November, pp. 27-37.

BUCLET Nicolas, 2005. "Vendre l'usage d'un bien plutôt que le bien lui-même : une piste pour concilier meilleurs prise en compte de l'environnement et rentabilité des entreprises", XV conférence internationale de RESER, Granada, 22-24 September 2005.

CASTElls Manuel, AOYAMA Yuko, 2002. "Une évaluation empirique de la société informationnelle: structures de l'emploi dans les pays du G7, 1920-2000". Revue Internationale du Travail, Vol. 141, $\mathrm{n}^{\circ} 1-2$, pp. 133-173.

CLARK Colin, 1940. The conditions of progress and security, MacMillan and co., Londres; trad. fr. 1960. Les conditions du progrès économique, Presses Universitaires de France, Paris, 500p.

DELAUNAY Jean-Claude, GADREY Jean, 1987. Les enjeux de la société de services, Les Presses de Sciences Po, Paris, 333p.

DESMARCHELIER Benoit, GALLOUJ Faïz, 2010. "Croissance endogène et politique environnementales : les processus de croissance et de tertiarisation des économies développées sont-ils réversibles ? Une perspective évolutionniste.”, RESER conference paper, Gothenburg, Sweden.

DJELLAL Faridah, GALLOUJ Faïz, 2005. "Un modèle d'analyse de la dynamique de l'innovation dans les services : le cas des services de types architecturaux", Économies et Sociétés, EGS, n7, pp. 1973-2010.

DU TERTRE Christian, 2007. "Des services aux entreprises à l'économie de la fonctionnalité : les enjeux du développement durable" in Heurgon Édith, Landrieu Josée (coord.). L'économie des services pour un développement durable. Nouvelles richesses, nouvelles solidarités, Colloque de Cerisy, Prospective, Essais \& Recherches, L'Harmattan, 390p.

EIGLIER Pierre, LANGEARD Eric, 1987. Servuction. Le marketing des services, Ediscience international, Paris, 205p. 
ETTIGHOFFER Denis, 1992. L'entreprise virtuelle. Ou les nouveaux modes de travail, Editions Odile Jacob, Paris, 346p.

FORAY Dominique, 2000. L'économie de la connaissance, La Découverte, Paris, 124p.

FOURASTIÉ Jean, 1949. Le grand espoir du XXème siècle. Progrès technique, progrès économique, progrès social, Presses Universitaires de France, Paris, 224p.; $2^{\text {nd }}$ edition, 1963, Gallimard, 372p.

FOURCROY Charlotte, 2010. Services et énergie. Formation de la demande d'énergie d'une activité de services, Mémoire de Master 2 Recherche ESII, University of Lille 1.

FUCHS Victor R., 1968. The service economy, National Bureau of Economic Research, New-York, 280 p.

GADREY Jean, 1991. “Le service n'est pas un produit. Quelques implications pour l'analyse économique et pour la gestion”, Politiques et management public, Vol. 9, n 1, March, pp. 1-24.

GADREY Jean, 1992. Socio-économie des services, Éditions La Découverte, Paris ; 3rd edition, 2003, 124p.

GADREY Jean, 1994. "Les relations de service et l'analyse du travail des agents". Sociologie du travail, $n^{\circ} 3$, pp. 381-389.

GADREY Jean, 2010. "The environmental crisis and the economics of services: the need for revolution", in DJELLAL Faridah, GALLOUJ Faïz, The handbook of innovation and services, Edward Elgar, Cheltenham.

GALLOUJ Faïz, 1999. "Les trajectoire de l'innovation dans les services : vers un enrichissement des taxonomies évolutionnistes”, Économies et Sociétés, Série EGS, n¹, 5, pp. 143-169.

GALLOUJ Faïz, 2002. Innovation in the service economy. The new wealth of nations, Edward Elgar, Cheltenham, 226p.

GALLOUJ Fä̈, WEINSTEIN Olivier, 1997. "Innovation in Services”, Research Policy, Vol. 26, $\mathrm{n}^{\circ} 4-5$, pp. 537-556.

GERSHUNY Jonathan I., 1978. After industrial society. The emerging of self-service economy, MacMillan, Londres, 181p.

HILL T.P, 1977. "On goods and services”, Review of Income and Wealth, Vol. 23, n4, December, pp. 315-338.

HILL T.P, 1999. "Tangibles, intangibles and services: a new taxonomy for the classification of output”, Canadian Journal of Economics, Vol. 32, n², April, pp. 426-446.

IFEN, 2004. "La tertiarisation de l'économie et la réduction des émissions de CO2", Les données de l'environnement, lettre thématique mensuelle de l'IFEN, n95, September, 4p. 
ILLERIS Sven, 1989. Services and regions in Europe, Avebury, Aldershot, 222p.

ILLERIS Sven, 2007. "The nature of services", in Bryson John R., Daniels Peter W. ed.. The handbook of service industries, Edward Elgar, Cambridge, 504p., pp. 19-33.

LEVY Maurice, JOUYET Jean-Pierre, 2006. «L'économie de l'immatériel. La croissance de demain», Rapport de la commission sur l'économie de l'immatériel pour le Ministère de l'économie.

LOVELOCK Christopher, WIRTZ Jochen, LAPERT Denis, 2004. Marketing des services, Pearson Education, Paris, $5^{\text {th }}$ ed., 619p.

MAIRET Nicolas, 2009. Déterminants de la demande d'énergie dans le secteur tertiaire en France, une analyse technico-économique, Thèse de doctorat en Sciences économiques, Montpellier 1, soutenu en décembre.

MCCLELLAND David C., 1985. "How motives, skills, and values determine what people do", American Psychologist, Vol. 40, nº, pp. 812-825.

OCDE, 2000. The service economy, OECD Publications, Paris.

RIFKIN Jeremy, 2000. "Quand tout devient service" in Rifkin Jeremy. L'âge de l'accès : la révolution de la nouvelle économie, La découverte, Paris, 395p., pp. 99-127.

ROMM Joseph, ROSENFELD Arthur, HERRMAN Susan, 1999. The internet economy and global warming, The Center for Energy and Climate Solutions

SAY Jean-Baptiste, 1803. Traité d'économie politique ; 1972. Calmann-Levy, Paris, 571p.

SESSI, 2008. Tableau de bord des TIC et du commerce électronique, Édition décembre 2008, Ministère de l'Économie, de l'Industrie et de l'Emploi. Consulté le 18 juin 2010. URL : http://insee.fr/sessi/tableau_bord/tic/tic.html

SISMONDI JCL Simonde de, 1819. Nouveaux principes d'économie politique ou De la richesse dans ses rapports avec la population; 1971, Calmann-Levy, Paris, 376p.

SKOLKA Jiri V., 1976. "The substitution of self-service activities for marketed services", Review of Income and Wealth, Vol. 22, n ${ }^{\circ}$, December, pp. 297-304.

SMITH Adam, 1776. The wealth of nations. Book 2 ; 1970. Editions Penguin Books, Londres, 535p.

STEHR Nico, 2007. "Theories of the information age", in Bryson John R., Daniels Peter W. ed.. The handbook of service industries, Edward Elgar, Cambridge, 504p., pp. 19-33.

WALKER Richard A., 1985. "Is there a service economy? The changing capitalist division of labor", Science and society, Vol. XLIX, ${ }^{\circ} 1$, Spring, pp. 42-83. 
WILLIAMS Eric, TAGAMI Takashi, 2003. "Energy use in sales and distribution via e-commerce and conventional retail. A case study of the Japanese book sector", Journal of Industrial Ecology, vol.6, $\mathrm{n}^{\circ} 2$, pp. 99-114. 